\title{
HISTÓRIA E MEMÓRIA NA VOZ DO SOCIÓLOGO MOÇAMBICANO JOSÉ LUÍS CABAÇO
}

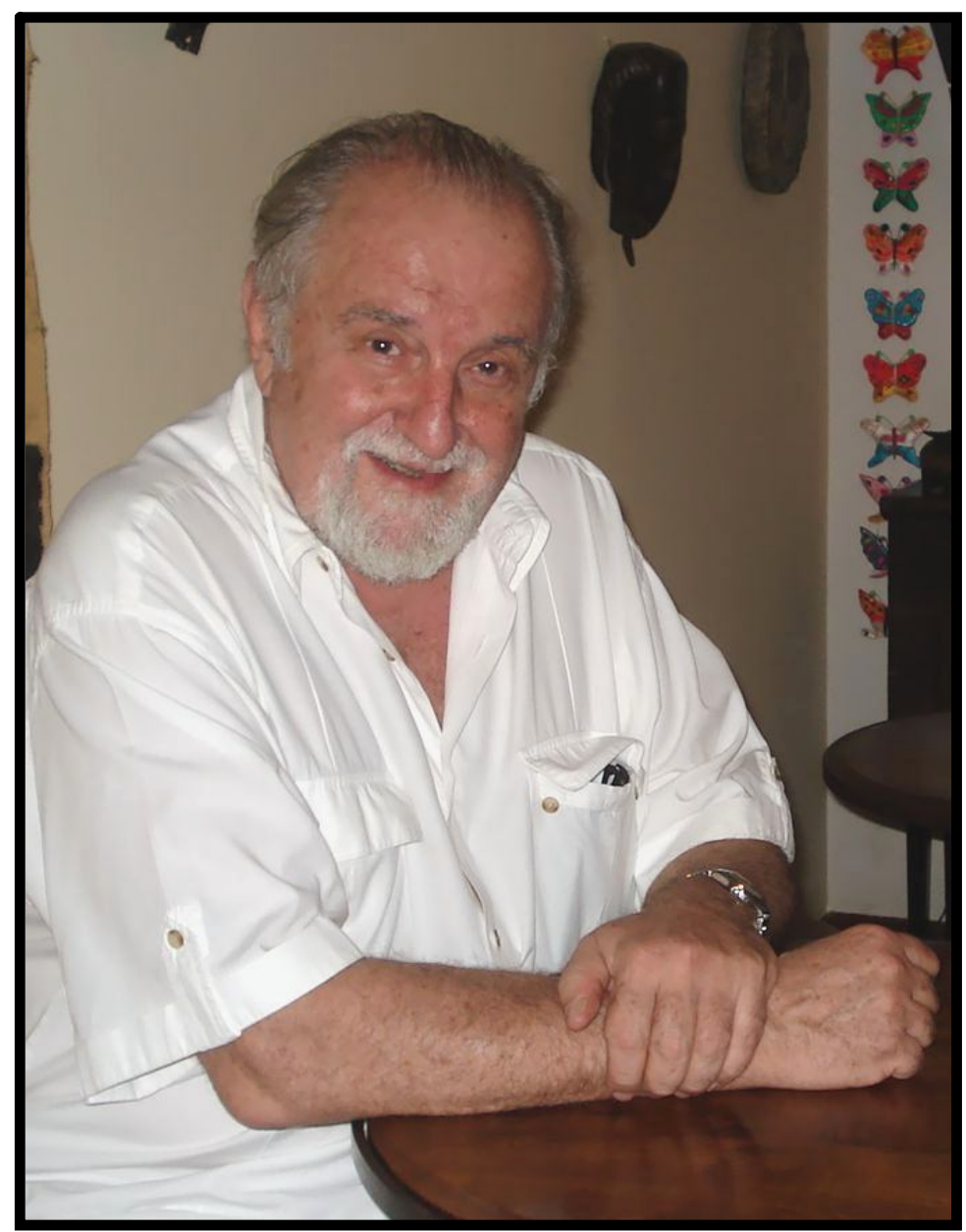

Foto: Genivaldo Rodrigues Sobrinho
As memórias e os relatos de José Luís de Oliveira Cabaço sobre tempos de lutas e construções em Moçambique são, sem dúvida, uma fonte de conhecimento para quem busca entender 0 processo histórico moçambicano. Ministro dos Transportes e Comunicações posteriormente Ministro da Informação no governo de Samora Machel, José Luís Cabaço viveu ativamente os periodos conturbados da História de seu país e, recentemente, defendeu, na Universidade de São Paulo (USP), a tese de doutorado intitulada Moçambique: identidades, colonialismo $e$ libertação, em que discute as ideologias e políticas identitárias do periodo colonial até independência.

Por Avani Souza Silva, Érica Antunes Pereira, Flávia C.

Bandeca Biazetto e Flávia Merighi Valenciano

Revista Crioula - O senhor, como sabemos, tem vivido parte de seu tempo no Brasil, mais especificamente em São Paulo, e parte na maior cidade de Moçambique, Maputo. O senhor diria que a vida em São Paulo e em Maputo, guardadas as devidas proporções, mantém 
semelhanças inegáveis quanto à composição dos ambientes sociais, ou seja, recebimento de migrantes de áreas mais empobrecidas do país, desigualdades sociais, exploração da mão-de-obra com baixos salários, trabalhos informais, serviços públicos deploráveis, insensibilidade das classes mais bem posicionadas, preconceitos sociais e raciais e uma infinidade de situações que se cristalizaram ao longo de nossas respectivas histórias?

José Luís - É importante distinguir o que entendemos por semelhanças ou diferenças. O que Maputo e São Paulo têm em comum estende-se a outras centenas de cidades-capitais (distritais, provinciais, estaduais ou nacionais), resultado de realidades coloniais, espalhadas na sua maioria pela metade sul do mundo: todas elas, em relação aos espaços geográficos em que estão inseridas, constituem pólos de atração, centros de oportunidades de melhoria da situação de vida, locais de ostentação de riqueza e, paralelamente, vitrines de desigualdade social, de segregação e de marginalização. Entre São Paulo e Maputo, por outro lado, há duas realidades muito diferentes marcadas pela distância da experiência colonial num e noutro país. Além disso, a cidade de São Paulo é uma metrópole e tem capacidade de se afirmar em termos mundiais, o que não acontece com a cidade de Maputo, que é periférica e depende das decisões tomadas no exterior. Em outras palavras, a personalidade de Maputo não se revela na capacidade de interlocução, mas sim em outros aspectos, como a capacidade de resistência, por exemplo, que, talvez, seja mais vigorosa que em São Paulo. Essa questão das semelhanças e diferenças é, como se vê, muito complexa. Há uma corrente de pensamento muito perigosa que procura estabelecer semelhanças no fato de que compartilhamos uma língua oficial. Eu discordo totalmente de que isso seja uma "semelhança": eu a vejo como uma herança sobre a qual é preciso essencialmente refletir, mas não quero alongar-me sobre esse tema. Regressando à comparação entre as duas cidades referidas, eu diria que ela é muito mais marcada por aquilo que as distingue: São Paulo é uma 
metrópole industrial e financeira que se aproxima mais dos países do centro, enquanto Maputo é um típico exemplo de cidade pobre da extrema periferia mundial. São Paulo é uma cidade recheada de história pela sua autonomia dentro da Federação, com um dinamismo cultural de vanguarda, um centro de pesquisa científica que é referência internacional; nela, se fundem, com influência, diferentes colonizações que plasmam uma realidade multicultural riquíssima. Maputo vive ainda a síndrome da cidade conquistada. Foi "do norte" que veio a liberdade e a luta, e o modelo de que ela foi portadora foi forçado a uma interação, muitas vezes traumática, com a sociedade urbana herdada do colonialismo derrotado. As polaridades desse choque ainda não estão harmonizadas. A divisão internacional do trabalho relegou Maputo à condição de prestadora de serviços e condenou a maioria de sua população à sobrevivência pela informalidade. A situação financeira de Moçambique não permite ao Estado os investimentos necessários para se criar uma dinâmica de desenvolvimento real. A iniciativa privada - $\mathrm{e}$ grande parte dela é estrangeira - não tem o bem público como primeira prioridade, e a relação entre investimento e distribuição social é cada vez mais deficitária. Por fim, para compreender as diferenças gritantes entre as duas realidades, basta recordar que a população da região metropolitana de São Paulo é quase igual à população total de Moçambique, país com quase 900 mil quilômetros quadrados. Maputo, com o seu milhão e meio de habitantes, tem menos gente do que a maioria dos bairros desta cidade...

RC - Trinta e dois anos de independência são suficientes para se traçar um panorama do que é a nação moçambicana?

José Luís - Ah, não! Trinta e dois anos, na vida de uma nação, são trinta e dois dias na vida de um homem. Na verdade, nunca há um momento em que uma nação se caracteriza cem por cento: ela está sempre em transformação. Em Moçambique, mais que em transformação, a nação está em formação: há um processo de 
sedimentação de experiências que tem sofrido, muitas vezes, turbações radicais que revolvem o que se estava sedimentando. Nós passamos por vários períodos - nacionalista, socialista, de guerra, neoliberal - num espaço de apenas trinta e dois anos; tivemos experiências demasiado profundas por conta do sofrimento que caracterizou esses anos, mas consolidamos escasso conhecimento da experiência com outros povos. Trinta e dois anos representam, ainda, um período de descoberta: ainda estamos "pondo o dedo na tomada para ver se dá choque". De qualquer forma, alguma definição da realidade moçambicana se sedimentou nesse período; o moçambicano sabe que não é outra coisa - não é malawiano, zambiano, zimbabueano etc. Já há uma consciência bastante mais alargada dessa pré-identidade, embora ainda não estejamos longe de saber o que é um moçambicano. Mas vocês, com quase duzentos anos de independência, sabem o que é exatamente um brasileiro? Para dar um exemplo: quando chegou a Moçambique, em 1988, a nova embaixadora americana, eu a acompanhei numa viagem pelo país para que ela pudesse ficar com uma primeira "gestalt" da situação moçambicana. Visitamos, na ocasião, um grande campo de refugiados nos arredores da cidade de Tete, no alto Zambeze - na verdade, o campo ficava em Moatise, do outro lado do rio - e encontramos uma família de Morrumbala, que fica na província da Zambézia, a uns $500 \mathrm{~km}$ dali. Ficamos intrigados com aquilo, pois eles poderiam ter fugido para o Malawi, por exemplo, onde falariam a mesma língua e teriam, certamente, laços familiares. Responderam-nos que, em princípio, tinham fugido para lá, mas que, como não se tinham adaptado "à maneira de viver do Malawi", resolveram se instalar naquele campo, e ali encontraram outras famílias da região de Morrumbala. Aquele episódio tem-me feito refletir sobre a questão e penso, hoje, que um dos elementos que contribuem para essa identificação em torno do nome de um país é a representação que se tem do Estado e a relação que se estabelece entre o cidadão e o Estado e vice-versa. Esses vários componentes fazem com que um indivíduo que nasce, vive e se socializa em Moçambique se sinta paulatinamente 
distanciando-se de outro que, pertencendo ao mesmo grupo etnolingüístico, vive em outra realidade sócio-econômica, em território político diferente. Nesse aspecto, há o processo de gradual e não-linear caracterização de uma forma moçambicana de viver que, somado a outros fatores, acabará consolidando uma nação moçambicana ao longo do tempo. Mas se esse processo é mais visivel nas regiões urbanas, ele é muito mais profundo e emocional nas áreas rurais.

RC - Em aula ministrada na Faculdade de Filosofia, Letras e Ciências Humanas da USP, no dia 28 de agosto de 2007, o senhor se referiu à guerra civil em Moçambique como uma "guerra inventada". O que significa isso?

José Luís - Sem lhe tirar o caráter de guerra civil, na qual o conflito se converteu, pretendi enfatizar a sua gênese. Há duas interpretações tradicionais e simplistas sobre a guerra que assolou Moçambique depois da independência: uma afirma que ela é o resultado de uma insatisfação das populações em relação ao governo e a outra diz que se trata de uma guerra conjuntural e de agressão dirigida pelo exterior. A minha leitura da guerra é um pouco diferente: após a independência, foram criadas bolsas de insatisfação. Umas nas zonas urbanas, entre moçambicanos aculturados pela presença portuguesa e comprometidos de qualquer forma com o estado colonial; outras nas zonas rurais, devido à destituição do poder das linhagens tradicionais e pela ação repressiva que o projeto de modernização exercia sobre algumas práticas tradicionais. A cultura tradicional, ao contrário do que muitas vezes se diz, não é uma cultura estática; ao contrário: ela é altamente dinâmica, adapta-se sistematicamente aos novos condicionalismos da sociedade para defender a essência de sua cosmovisão e de seu poder. Algumas práticas tradicionais tornam-se historicamente obsoletas mesmo sem a repressão do governo, mas a estrutura da ordem tradicional as reconverte e assegura sua sobrevivência nessa negociação com os novos poderes; se necessário, clandestiniza-se e reorganiza-se 
esperando o momento de ressurgir à luz do dia. Mas, retomando o que afirmei há pouco: as áreas de descontentamento ou de insatisfação que se criaram não tinham, em minha opinião, um potencial de contraposição com o Estado (o poder), pois essa não é a sua tradição; sua tradição é a negociação permanente, e ela estava longe de se ter esgotado. O tipo de contradição que se criara afetava setores da população que carecem de organização e coordenação fora dos limites da própria comunidade e que não estruturavam sua insatisfação num discurso orgânico alternativo.

Em 1977, aplicamos as sanções internacionais decretadas contra a Rodésia e, além disso, decidimos apoiar o movimento de libertação do Zimbábue. Ocorre que, com a independência, muitos portugueses e alguns moçambicanos que tinham lutado no exército português principalmente nas tropas especiais - tiveram receio de retaliações e fugiram para os territórios vizinhos, em particular o da Rodésia. Muitos desses refugiados tinham grande experiência militar, o que atraiu a atenção dos serviços de inteligência especiais rodesianos que, então, decidiram organizar unidades especiais para se infiltrarem em território moçambicano e combater os zimbabueanos. Tais unidades não representavam então uma rebelião dos moçambicanos, mas uma guerra conduzida do exterior com um objetivo extremamente preciso, ligado à segurança interna e à sobrevivência do regime minoritário e racista. Os rodesianos constataram com surpresa que o exército moçambicano, porque saído de uma guerra de guerrilha e em processo de transformação em força regular, se revelava pouco organizado e motivado. Perceberam que havia ali um potencial de pressão militar sobre o governo de Moçambique. Nesse período, havia, no centro de Moçambique, alguns campos de reeducação militar. Eles tinham sido criados no meio da floresta e o seu isolamento representava o principal obstáculo às fugas. As guarnições desses campos eram pequenas: 12 ou 15 policiais. Os campos eram, portanto, muito vulneráveis a uma operação militar e o exército rodesiano, informado por evadidos de um deles, organizou um ataque a esse campo onde estavam detidos antigos 
colaboradores do exército colonial português e militares da FRELIMO acusados de irregularidades diversas. Aí estavam duas personalidades que se viriam a destacar no comando da RENAMO: André Matsangaíce e Afonso Dhlakama. Metade dos prisioneiros do campo decidiu seguir com os rodesianos e a outra metade optou por ficar. O grupo que seguiu com os rodesianos - cerca de 150 ou 180 homens - engrossou as fileiras do corpo militar especial do exército da Rodésia. Posteriormente, graças à pressão de um português-moçambicano chamado Orlando Cristina - um militar, caçador e aventureiro bastante inteligente - os rodesianos ajudaram a que essas unidades se apresentassem como força independente do exército, assumindo publicamente o aspecto de uma força autonomizada: surgiu, assim, o MNR (Mozambique National Resistance), que, mais tarde, daria lugar à RENAMO.

Em 1980, com a queda do regime rodesiano, os movimentos nacionalistas venceram as eleições, cessando a função estratégica dessas unidades especiais. Quando se pensava que o exercício se extinguiria, os militares rodesianos fizeram um acordo com os sulafricanos e o grupo foi transferido para a África do Sul, onde foi reestruturado e potenciado. A África do Sul tinha uma capacidade muito maior que a Rodésia, o que garantiu uma nova estrutura ao grupo, ainda a serviço de uma conjuntura regional, a chamada "política de desestabilização dos países independentes da África Austral”, com a qual o apartheid procurava sobreviver. A estratégia adotada em Moçambique foi a destruição sistemática de todas as infra-estruturas e unidades produtivas nas zonas rurais, criando uma atmosfera de terror e obrigando as populações a se refugiarem ou, ainda, oferecendo proteção e apoio nas estruturas da RENAMO. A destruição causada resultava na dispersão completa das populações, dilacerando o tecido sócio-econômico que a FRELIMO procurava fomentar. Adolescentes de 12 a 16 anos foram incorporados nas forças rebeldes. Eram tecnicamente "raptados" das aldeias mediante um processo de recrutamento muito dramático, forçando esses adolescentes a cometerem publicamente crimes na própria comunidade e cortando- 
lhes, desse modo, a possibilidade de regressarem a casa na eventualidade de uma deserção. Evitava-se, assim, que essas crianças e adolescentes tivessem uma retaguarda psicológica. Nessa época, foram destruídas cerca de 980 escolas e 1200 hospitais, causando uma desestruturação social profunda nas zonas rurais. A presença do Estado quase não se fazia sentir e as estruturas tradicionais emergiram como organização indispensável à sobrevivência física e psicológica das populações. Elas constituíam um ponto de referência profundamente radicado no substrato cultural das gentes. As hierarquias tradicionais interpretavam toda aquela situação como o resultado da política da FRELIMO, ou seja, diziam que os espíritos estavam zangados porque a FRELIMO não havia respeitado as tradições. Paulatinamente, no curso desse processo de desagregação das estruturas estatais no campo, a RENAMO foi se organizando e passou a representar uma força de proteção, acolhendo e incorporando as expressões de descontentamento (e de indignação) existentes e agravadas pelo conflito em curso. Por volta de 1983 ou 1984, em minha opinião — não é a opinião da maioria —, a guerra de agressão começou a se transformar numa guerra social ou, mais que isso, numa guerra interna entre moçambicanos divididos por esse processo dilacerante. Penso que falar em uma guerra civil até 1983 é incorreto e, do mesmo modo, é incorreto falar de uma guerra de agressão depois de 1986, pois, no decurso desses anos, uma se transformou na outra - de qualquer modo, com o objetivo de deter ou conquistar o poder político. Mas há todo um processo de desenvolvimento e transformação da guerra que me leva a crer que se trata de uma guerra "criada" na sua fase inicial e que, depois, adquirindo sua própria dinâmica, passa a ser uma guerra intestina do país. Como já disse, quando afirmo que é uma "guerra montada", quero dizer que teve sua motivação primária e sua organização inicial determinadas pela conjuntura regional que opunha os países independentes aos países racistas e colonialistas ainda existentes nessa época. Para mim, é claro que essa "guerra inventada", no seu desenvolvimento, incorpora e potencia os elementos sociais de dissenso 
e se transforma, efetivamente, numa guerra civil até o final. Há dois aspectos interessantes que caracterizam essa guerra: inicialmente, a RENAMO diz que defende o projeto ocidental neoliberal contra o socialismo e a FRELIMO, afirmando-se socialista, apresenta-se como uma força patriota liderando a resistência contra uma ingerência estrangeira. O tempo reduziu tudo à conversa! Rapidamente a situação se deteriorou e se transformou num conflito em que cada lado lutava pela sua sobrevivência política e física. É nesse quadro de confrontação entre as duas "elites" que a FRELIMO faz o acordo com o FMI e substitui a economia estatal por uma economia privada, "comprando" - com surpreendente facilidade, diga-se de passagem - o pacote neoliberal, o que inicialmente parecia ser o projeto programático da RENAMO. Assim, temos hoje uma situação anacrônica: o programa político, econômico e social que prevalece no país é o enunciado inicialmente pela RENAMO, mas o poder político continua nas mãos da FRELIMO. Podemos dizer, na prática, que a RENAMO venceu ideologicamente e a FRELIMO venceu politicamente, uma vez que continua no poder. A partir de 1987/1988, não há nenhuma diferença de fundo entre os enunciados programáticos da RENAMO e os da FRELIMO. Em 1992, com a assinatura do acordo de paz, não houve mais incidentes, as pessoas tranqüilamente cumpriram os programas, voltaram para casa e tudo ficou normal. As áreas de atrito permanecem, desde então, ao nível das ambições individuais das elites.

$\mathrm{Na}$ altura, havia o grande problema do regresso das crianças que haviam assassinado as pessoas de sua aldeia no momento do recrutamento. A comunidade internacional - e muitos de nós - estava muito preocupada com isso, de modo que foram contratados técnicos internacionais, convocados psicólogos e sociólogos, mobilizados religiosos e assistentes sociais para enfrentarem o problema. No entanto, na grande maioria dos casos, esse problema já estava resolvido pela capacidade de adaptação das sociedades tradicionais, com recursos aos rituais de "despossessão". Numa descrição simplista, digamos que, na cosmogonia tradicional, o corpo humano é 
basicamente um contentor que é possuído e ocupado pelos espíritos: quando alguém vai para a guerra, é tomado pelo espírito mau e, por isso, mata e faz barbaridades. Saindo da guerra, é preciso "despossessar" o indivíduo do espírito mau e "reapossessá-lo" do espírito bom, da paz. Ninguém pode matar um corpo que tem um espírito bom, só podia fazê-lo durante a guerra, quando tinha o espírito mau. Ao chegarem os profissionais para falar sobre a guerra, as comunidades ficaram incomodadas e, em muitos casos, correram com eles, já que falar de guerra significava trazer de volta os espíritos maus. Essas são questões muito interessantes sobre essa comunidade internacional que nos governa e sobre nós que somos governados.

RC - Com a Guerra Civil, houve intensa migração dos moçambicanos do campo para a cidade, principalmente dos mais velhos e das crianças, trazendo na bagagem tradições e ritos ancestrais que jamais foram subjugados totalmente pelo colonizador. De que maneira esse fato influenciou a cultura e as tradições moçambicanas na formação da sociedade urbana, em especial nos principais centros, como Maputo?

José Luís - Eu diria o seguinte: a grande transformação da cidade se dá com a independência. As cidades todas, em especial Maputo, que conheço bem, são geograficamente divididas, no tempo colonial, em dois grandes blocos: a "cidade de cimento" e "o caniço" (porque as construções tradicionais são feitas de caniço, um bambu fino). Em Lourenço Marques (hoje Maputo), as duas eram divididas por uma rua, chamada Estrada da Circunvalação. Essa Estrada marcava os limites da "cidade", como os colonos a viam, como a "cidade dos civilizados". Note-se que a Circunvalação era chamada de Estrada e não de Rua, indicando que a "verdadeira cidade" morria na beira dessa estrada. Do outro lado, começavam os "subúrbios", a "não-cidade dos indígenas". Uma divisão espacial e conceptual bem marcante.

Com a independência, houve dois fenômenos nas cidades: de um lado, a sua relativa desocupação pelo abandono dos colonos, e, de outro, o 
desaparecimento, com a emancipação política, de algumas barreiras psicológicas, raciais, etc. O parque imobiliário de cimento pertencia integralmente aos colonos. Na verdade, a maior parte dos apartamentos de rendimento encontrava-se hipotecada aos bancos. Depois da independência, os colonos usaram este seu poder de propriedade de uma forma humilhante. Aumentava de dia para dia o número de apartamentos livres pelo abandono dos colonos que deixavam Moçambique, mas os proprietários recusavam alugar esses apartamentos livres aos africanos, principalmente se negros. Esse fato gerou um estado de insatisfação enorme na população urbana e levou o governo a, em 4 de fevereiro de 1976, anunciar o processo de nacionalização dos prédios de rendimento, impedindo a especulação imobiliária. Com isso, houve uma invasão das cidades pelas populações periféricas, de modo que bairros que eram tradicionalmente brancos ficaram, de repente, quase exclusivamente negros. Esse foi o grande momento de transformação das cidades.

É verdade que essas populações, num primeiro momento, eram já populações praticamente urbanizadas ou peri-urbanas que tiveram acesso a uma plataforma de vida diferente. Porém, quem conseguiu um apartamento ou casa grande começou a receber família do campo, com hábitos bastante diferentes. Esse primeiro movimento - que eu chamo de ruralização das cidades - começou exatamente na decorrência do processo de nacionalização das casas e se intensificou com o êxodo dos refugiados de guerra. A novidade que a guerra causou à cidade são as famílias desenquadradas, são pessoas que fogem para a proteção da cidade, mas que com ela não têm laços, fato que traz à tona o fenômeno das crianças e velhos abandonados. Habitualmente, não há, na sociedade africana, velhos abandonados, já que estes são considerados um patrimônio e uma responsabilidade da comunidade. No entanto, com a desagregação das famílias provocada pela guerra no campo, aparecem velhos fugidos que, sem família e referenciais comunitários em que se apoiar, permanecem à mercê da própria sorte. O mesmo vale para as crianças. Surge o fenômeno das crianças de rua. 
No final dos anos 80, o período mais dramático da guerra, Moçambique se tornou o país mais pobre do mundo e as cidades tiveram um processo de degradação muito acentuado: tanto porque as infraestruturas urbanas estavam superlotadas para seu dimensionamento normal, quanto porque o Estado e os municípios não tiveram capacidade para aumentá-las e acolher, com eficácia, a população que continuava crescendo. Depois da guerra, as cidades foram sendo paulatinamente reconstruídas e hoje, na maioria delas, se a situação está longe de ser ótima, pelo menos é muito diferente, para melhor, da que havia nos fins dos anos 80 .

RC - Qual foi o impacto da política de identidade nacional proposta pela FRELIMO - o "homem novo" - nas sociedades tradicionais? E como essa política legitimou o novo poder político pós-independência?

José Luís - A política do homem novo deve ser vista na sua gênese dentro da questão da resposta global que a FRELIMO dá à realidade colonial. A FRELIMO nasce de uma situação antagônica ao colonialismo e de uma situação profundamente rural, de modo que o sentido de comunidade-unidade era fundamental para o sucesso da guerrilha e advinha das próprias comunidades tradicionais. Era preciso contrapor cada valor da sociedade colonial com um valor alternativo, evitando-se que este fosse contaminado pela cultura daquela. Por outro lado, a FRELIMO, como um movimento nacional, incorporava, na sua estrutura, gente de todas as partes do país, com línguas e costumes diferentes. O essencial era estabelecer um projeto de unidade nacional. Para isso, criou-se um ritual de transição, verdadeiro rito de passagem, extremamente interessante e que se chamava "narrativa de sofrimentos": quando qualquer novo guerrilheiro se apresentava para se incorporar nas fileiras da FRELIMO, devia contar, perante todos, a sua história pessoal e a razão de querer arriscar sua vida para lutar pela liberdade do país. Isso normalmente se traduzia num conjunto de narração de sofrimentos. Mas, além de promover a integração e a 
motivação entre os membros, havia outro motivo para a adoção de tal procedimento: a identificação completa do sujeito. Já que a história pessoal era revelada a todos, a dificuldade de mentir era muito grande, o que garantia a segurança da FRELIMO e, ao mesmo tempo, selava um compromisso do indivíduo perante a comunidade. Criava-se, assim, uma plataforma de unidade à volta do sofrimento, da experiência colonial, e esse era o ponto de partida do discurso da unidade nacional. Na seqüência disso, a FRELIMO organizava as unidades militares de preferência juntando gente de vários pontos do país, pois isso reforçava a solidariedade. Em outras palavras, a experiência comum ampliava-se através de uma experiência de guerra. A idéia era criar uma base comum a todas as experiências culturais e, sobre elas, construir uma nova identidade moçambicana. Havia, naturalmente, pessoas que vinham de uma sociedade que premiava o individualismo, nesse caso a FRELIMO contrapunha com uma idéia de sociedade que defendia o comunitarismo; havia pessoas que vinham de uma sociedade competitiva, a FRELIMO propunha um valor de colaboração, camaradagem etc. Assim, o "homem novo" acabava por ganhar um perfil exatamente na contraposição do inimigo e criava também defesas de caráter psicológico e ideológico para se distanciar do outro. À medida que a FRELIMO se politiza e ganha estrutura ideológica, acaba por criar o "modelo do homem novo" segundo o qual o indivíduo incorpora valores que não the são inatos, mas adquiridos no decurso do tempo. É muito interessante ver que um discurso que nasce com uma matriz profundamente materialista (a transformação através de uma prática social, através de relações sociais de produção de natureza diferente das existentes sob o colonialismo) acaba por se diluir numa matriz idealista, numa abordagem moralista. O discurso do "homem novo" tem, como eu disse, uma certa justificação e uma certa vida enquanto existe a confrontação direta com o inimigo, enquanto as relações sociais são plasmadas pela luta de libertação nacional. Mas quando se conquista a liberdade e se restabelece a paz, o inimigo se esfuma como realidade concreta e passa a ser um inimigo de longe, mais abstrato, etc. $\mathrm{O}$ 
discurso vai então perdendo consistência. A natureza das relações de produção não é alterada, e esta é a questão central. Além disso, o discurso do "homem novo" numa realidade urbana comporta muito mais variáveis que aquelas que a FRELIMO se habituara a controlar numa situação de guerra e num contexto rural. Nesse sentido, o discurso do "homem novo" torna-se prescritivo, um discurso cada vez mais moralista e autoritário que se distancia da vida quotidiana das cidades e, posteriormente, da própria realidade no campo. O regime, então, adquire um caráter de autoritarismo crescente justo pela incapacidade de transformar qualitativamente as relações sócioeconômicas e de gerir as diversificadas dinâmicas sócio-culturais novas que se lhe deparam. É por isso que o discurso do "homem novo" se torna algo completamente idealista e se extingue.

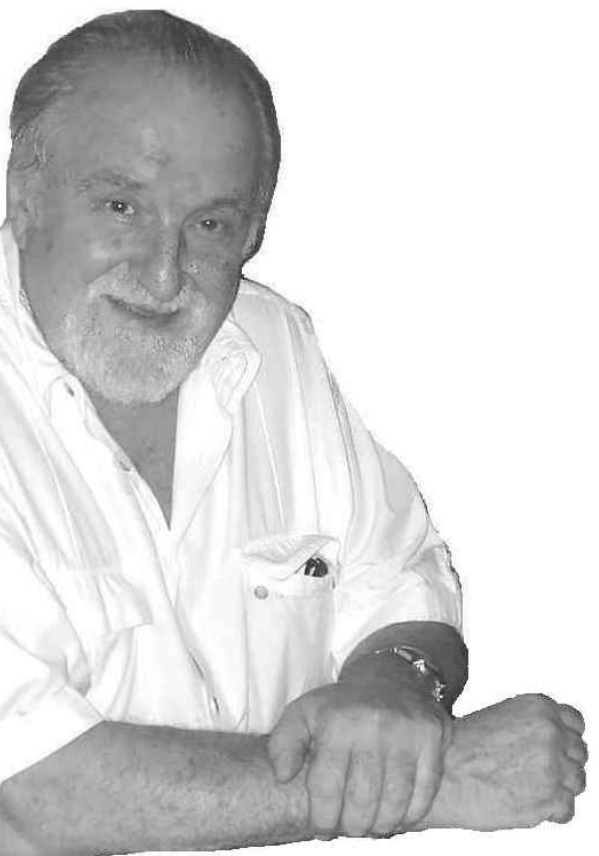

RC - Chama a atenção quando o senhor fala do processo de seleção pela FRELIMO, em que as pessoas tinham que contar a própria vida e a experiência. Este uso da palavra, opondo-se ao silenciamento que caracteriza a posição do colonizado, liga-se, de alguma forma, ao resgate da tradição e da oralidade?

José Luís - Sem dúvida. O sucesso daquele rito de passagem, a "narração de sofrimento", como era chamado, foi total. Aquilo foi determinante na estratégia política da FRELIMO no tempo da luta de libertação nacional. Eu, como militante da clandestinidade, só passei por ele mais tarde e senti, então, o impacto psicológico da sua realização. Depois de apresentar a minha história perante um amplo grupo de companheiros de partido senti-me finalmente parte integrante 
do processo revolucionário anti-colonial no qual militava já há oito anos.

RC - Então quer dizer que, de fato, foi uma estratégia da FRELIMO a utilização dos recursos da tradição?

José Luís - Foi de certa maneira. O problema é que a FRELIMO, em minha opinião, foi realmente vitoriosa na estratégia só até a libertação nacional ou, talvez, no primeiro ou segundo ano depois da independência. Depois, começa a perder um pouco o controle de uma sociedade que era demasiado complexa para os instrumentos que tinha desenvolvido na luta de libertação nacional. E como vinha com aquela idéia defensiva de recear a contaminação da sociedade urbana, capitalista, colonial, etc, a relação com os quadros potenciais que esta sociedade podia ter dado para a reconstrução nacional foi sempre desconfiada; eles nunca se sentiram à vontade porque estavam longe daquele modelo do "homem novo". A situação em Moçambique é diferente da que aconteceu, por exemplo, em Angola. Nesse país-irmão, houve uma guerra de agressão por parte dos sul-africanos logo a seguir a independência, o que fez com que toda a gente ficasse envolvida no processo da defesa nacional. Isso determinou um aproveitamento muito maior dessas capacidades na sociedade angolana do que na moçambicana.

RC - O senhor diria que, em pouco mais de três décadas, já há, em Moçambique, uma amnésia histórica com relação às guerras de independência e civil?

José Luís - Eu diria em que todas as sociedades há uma amnésia histórica, não é nenhuma particularidade de Moçambique. Quando a gente, aqui no Brasil, fala com a nova geração sobre a ditadura, poucos jovens sabem do que estamos a falar. Recentemente, vi, na internet, que, em Portugal, fizeram um inquérito sobre o 25 de abril: 
perguntaram por que era feriado e as pessoas, sobretudo os jovens, não sabiam, não tinham a mínima idéia do que tinha havido em 25 de abril de 1974 e que justificasse o feriado. A amnésia histórica só não se verifica, digamos assim, de forma generalizada, se existir uma persistência do regime político em incorporar a História no sistema da educação, para passar de geração em geração. No caso de Moçambique, o grupo de poder que faz a viragem radical permanece na ribalta da vida política. Nós tivemos a sorte de ter tido um grande líder da independência, que foi o primeiro presidente, Samora Machel, um homem invulgar, dotado de um carisma, de uma capacidade de direção e de uma popularidade absolutamente extraordinária que encantava inclusive seus adversários políticos. Quando Samora morre e é substituído, o novo presidente considerou imperativa uma transformação do "samorismo" - isso sequer ponho em discussão, porque provavelmente essa era, para ele, a única forma de terminar com a guerra -, mas a verdade objetiva é que ele transforma o sistema político de Moçambique no seu contrário e, naturalmente, a forma de fazer isso era "passando uma esponja sobre o passado". O interessante é que, depois de cerca de 30 anos, esse sistema começa agora a dar os primeiros sintomas de cansaço, de crise, e o referencial das pessoas volta a ser o Samora, renasce o mito de Samora Machel. Só para dar um exemplo, há uns 5 ou 6 anos, começaram a aparecer as carrinhas de transporte de passageiros - as aqui "vans", chamadas de "Chapa 100" em Moçambique - e os motoristas costumavam ligar o rádio para, no lugar de música, passar os discursos do Samora para os passageiros ouvirem. Um outro exemplo curioso é que, em 1994, eu tinha sido contratado pelas Nações Unidas para ser o oficial de informação pública da ONUMOZ, o corpo das Nações Unidas que estava lá para cumprir a transição em Moçambique. Eu trabalhava ao lado de funcionários internacionais e alguns deles me olhavam com alguma desconfiança quando eu, perguntado, descrevia o Samora como um líder carismático e de grande popularidade. Eles o viam como um ditador, porque condicionados pela propaganda que associava o socialismo com a 
ditadura. Enfim, houve as eleições, o Chissano ganhou e, no dia em que ia ser empossado na Praça da Independência, que ficava em frente ao edifício das Nações Unidas, junto à Catedral, os funcionários da rádio foram experimentar o sistema da comunicação sonora e puseram lá um discurso do Samora. Quando as pessoas começaram a ouvir aquilo, e eu sou uma dessas pessoas, foi uma emoção e uma comoção geral. Todo o mundo correu para a porta do edifício, em frente da praça. Entretanto, chegaram os funcionários internacionais e era visível a forma como ficavam estarrecidos perante a emoção e a "insubordinação" que a simples voz de Samora criara entre os moçambicanos, mesmo depois de 7, 8 anos de sua morte. O fato de Samora ser uma personalidade tão marcante, de alguma forma tornou mais difícil a vida do presidente que o sucedeu: por um lado, era preciso afirmar que seu modo de governar era diferente do de Samora, e por outro, para poder introduzir e conduzir um novo discurso ideológico e econômico no país, teve que organizar uma verdadeira "conspiração do silêncio" tentando romper com a memória do passado. Provocou-se essa fratura com um passado cheio de erros certamente, mas cheio de glórias, de ideais, de emoções, de projetos, e as novas gerações ficaram órfãs: desconhecem donde vêm. Quem não tem passado, tem dificuldade redobrada de se projetar no futuro. Agora há, efetivamente, uma reivindicação de setores crescentes da juventude de recuperar o passado. A figura do Samora surge como referência. Mas ela surge mitificada pelo tempo e pela semi-clandestinidade a que foi votado nesses anos. Representa, por enquanto, mais um esforço de busca do tempo da utopia que se perdeu do que de recuperação da memória histórica.

RC - Qual a importância da literatura na preservação da história moçambicana e, conseqüentemente, na construção da idéia de nação?

José Luís - Ao contrário da situação de Angola, nossa literatura, até hoje, não tem trabalhado muito com a História. Há o Ba Ka Khosa, que 
fez Ualalapi, e poucos além dele inseriram a história na literatura. O Mia Couto também escreveu $O$ outro pé da sereia, que fala sobre o século XIX, XVII, coisa assim. Mas são exemplos absolutamente esporádicos na nossa literatura. Angola tem uma literatura muito mais sistemática sobre a história, com pontos altos em Pepetela e Abranches, e que se prolonga na nova geração com Agualusa (para falar dos mais conhecidos aqui no Brasil). Em Moçambique, a literatura teve um papel muito importante no tempo colonial. Um pouco da utopia da nação está muito ligada principalmente à poesia moçambicana: Craveirinha, Noémia de Sousa, Rui Nogar e Kalungano são alguns dos nossos poetas da altura. Quando eu tinha os meus vinte anos, adorava ir à Associação Africana nos sábados à noite. Havia, com freqüência, espetáculos de música e dança popular africana e, terminado o espetáculo, alguns músicos ficavam por ali tomando uns copos e conversando e a eles se iam juntando outros músicos que tocavam noutros clubes ou locais. Nessa espera pelos outros músicos boêmios, era freqüente que se declamasse poesia (de autores moçambicanos, mas também de angolanos, cabo-verdianos e até de portugueses e brasileiros). Depois, os músicos começavam se desafiando com seus instrumentos e nasceram ali grandes sessões de jazz, principalmente de inspiração afro-americana. Eram noites de muita emoção. Toda a gente imaginava a utopia da liberdade. Isso foi caindo na segunda metade dos anos 1960, resultado da intensificação da repressão. Depois da independência, tivemos um período de alguns anos em que prevaleceu, digamos, a literatura de combate, a literatura retórica, ligada à luta de libertação, à epopéia e, muitas vezes, ao mau gosto. Tudo associado. Mia Couto foi uma das pessoas que rompeu com isso quando publicou o seu livro de poemas no princípio dos anos 80. Era uma poesia lírica, de amor, de angústia, de procura; é claro que ele é muito melhor escrevendo prosa, mas o livro já era muito interessante e curioso. Outro inconformado era o Luís Carlos Patraquim. A AEMO (Associação dos Escritores Moçambicanos), até então, estava dominada por um grupo de escritores que tinha vindo do período colonial, eram os consagrados, 
que sancionavam em grande medida a literatura dita de combate. Esse grupo fazia sentir seu peso histórico na vida da AEMO. Mia e Patraquim, à sua maneira, mantiveram aberta uma estreita passagem, mas quem rompeu com isso foi um grupo de jovens escritores que se organizou em torno de uma revista literária publicada sob a égide da AEMO, a Charrua. Faziam parte desse grupo o Ba Ka Khosa, o Eduardo White, o Armando Artur, o Marcelo Panguana, o Suleiman Cassamo, etc. Tratou-se de uma geração de jovens que se organizou numa espécie de movimento literário, procurando novos caminhos para a literatura, e entrou em conflito literário - e até, um pouco, conflito nas eleições com o velho grupo. Nunca houve ruptura, porque nós somos uma sociedade africana, e a sociedade africana não privilegia as rupturas, mas prefere soluções por recomposições sucessivas. No entanto, esse movimento literário não teve a repercussão que merecia na sociedade moçambicana do pós-independência, talvez porque a FRELIMO era um partido muito forte, assim como a personalidade do presidente Samora. Realmente, a literatura em Moçambique independente não teve o espaço social que conquistou em Angola ou mesmo em Cabo Verde. Em Moçambique, quem tinha realmente alguma influência era o Craveirinha. Teve um grande impacto na elite moçambicana o seu poema "As saborosas tangerinas de Inhambane", um grande poema em que critica desvios da FRELIMO. Suscitou, igualmente, uma certa efervescência, a publicação do Ualalapi pelo Ungulani Ba Ka Khosa. O livro surgia como um duplo ajuste de contas: com a tentativa de tornar Ngungunhane, o imperador de Gaza, um herói nacional e com o paralelismo que, nos inícios dos anos 1980, procurou-se estabelecer entre Ngungunhane e Samora, numa espécie de legitimação "tradicionalista" do seu poder. A desconstrução era oportuna, mas teria sido mais importante uns três ou quatro anos antes. Eu disse pra ele: "Escreveste um grande livro, mas escreveste um grande livro três anos depois do que deverias ter escrito. O livro deveria ter saído quando Samora era vivo e se procurava identificá-lo com Ngungunhane. O Craveirinha escreveu as "Tangerinas" quando todos estavam vivos... 
RC - E o Luís Bernardo Honwana?

José Luís - O Honwana, com vinte, vinte e um anos, escreveu um livro extraordinário, impressionante, e, depois, nunca mais publicou nada. Eu sou muito amigo dele, somos íntimos, e não é que ele deixou de escrever, tenho a certeza, só deixou de publicar. Não publicou sequer em jornais, nada! Considerou que tinha coisas mais importantes para fazer. Pessoalmente, penso que ele ficou, de certa forma, condicionado pelo sucesso que teve com o primeiro livro. Um segundo livro teria criado uma expectativa a que poderia não corresponder inteiramente. Então, como ele é um homem muito sábio, muito inteligente, muito controlado, conseguiu vencer a própria vaidade e não tornar público mais nada. Espero que, pelo menos, nos dê ainda um livro com as suas brilhantes reflexões sobre os problemas de Moçambique e da África contemporânea. Dele, tenho lido coisas dispersas e ouvido intervenções em debates e colóquios; tenho tido, sobretudo, o privilégio de conversar com ele: o que ele sabe e pensa não pode ficar às ocultas. Já disse isso a ele, que, sabiamente, sorriu e encolheu os ombros. Mas vai publicar um dia destes, estou certo.

RC - E quanto a Glória de Sant'Anna?

José Luís - A Glória de Sant'Anna é vista como uma boa e conceituada poetisa, mas, principalmente, como uma senhora extraordinária. Na região de Cabo Delgado, onde vivia, ela ficou muito mais conhecida e respeitada como pessoa que como poetisa. Ela era uma grande professora, todos os alunos que passaram pelas suas mãos ficaram com uma admiração, uma veneração por Glória de Sant'Anna. Em minha opinião, ela faz uma poesia que fica na franja entre a poesia colonial e a poesia moçambicana. O amor que ela tem por Moçambique faz com que sua poesia faça parte da poesia moçambicana, ainda que aqui e ali transpareça um certo paternalismo (maternalismo, no caso específico) 
com um certo odor luso-tropicalista... Quando converso com o Júlio Carrilho, pessoa por quem nutro grande estima e cuja delicada poesia tem influência forte da Glória de Sant'Anna, ele sempre se emociona ao falar da sua antiga professora. Eu não posso julgar o que não conheci e muito me impressiona esta humanidade que ela foi capaz de transmitir a tantos. É uma senhora de uma generosidade, honestidade e um altruísmo muito grande, isso ninguém põe em causa. Penso que acontece uma coisa interessante: se a pessoa tem, como Glória, uma boa formação moral — se bem que não gosto muito da expressão —, um espírito bom, generoso, altruísta, mas não tem a real percepção do mundo onde está, da sociedade colonial em que está envolvida, corre o risco de confundir as coisas. Glória, às vezes, confunde aquilo que, para mim, é uma característica atroz e dramática da situação colonial: havia bons que estavam do lado dos colonos e maus que, mesmo maus, estavam contra os colonos. Ou seja, a polarização da sociedade colonial nunca permitiu pontes. As pontes são psicológicas e, no caso de Glória de Sant'Anna, ela constrói uma ponte psicológica, mas a confunde com uma ponte real, que realmente nunca existiu, confunde aquilo que "é" com aquilo que "gostaria que fosse". A ambigüidade se estabelecia na relação entre o momento humano e o momento social. Os dois colidiam, mas essas pessoas não tinham a percepção disso, porque naturalizavam a relação social objetivamente injusta e julgavam a realidade pelo universo pessoal. Cria-se aqui uma situação de falsa consciência na qual as injustiças passam a ser percebidas como exceção a uma regra de naturalização das relações sociais. Isso é um pouco complicado de explicar, mas tal fenômeno marcou principalmente a última década do domínio colonial.

A percepção que tenho, e trata-se apenas de uma percepção minha, é que a compreensão deste fenômeno pode ajudar a compreender a poesia (e talvez a personalidade) de Glória de Sant'Anna. De todo modo, ela é uma pessoa muito estimada, que viveu em Moçambique alguns anos após a independência, depois voltou a Portugal e tem retornado, e é sempre recebida com grande carinho. Não creio que alguma vez 
alguém possa ter sido deselegante com ela, porque ela não deixou mágoas em Moçambique, e legou essa produção literária que não pode ser ignorada por quem estuda a literatura moçambicana. Sua produção literária não é, nem pode ser marginalizada; Glória é, com certeza, uma grande personalidade porque marcou todas as pessoas com quem teve contato.

RC - Em que medida a língua portuguesa pode ser considerada um elemento unificador nos países que a têm como língua oficial? Qual é o espaço que as línguas nacionais moçambicanas ocupam nos veículos de comunicação em Moçambique e como se dá a convivência entre as línguas nacionais e o português?

José Luís - As línguas nacionais foram rapidamente desprestigiadas pelo colonialismo. Foram degradadas ao ponto de as crianças, nas escolas, serem proibidas de falar as línguas maternas entre si; assim, o português era a língua oficial da escola autoritária. O colonialismo sempre combateu a valorização das línguas nacionais moçambicanas, colocando obstáculos a que elas se tornassem línguas escritas. É certo que houve alguns padres que fizeram estudos sobre as línguas, produzindo gramáticas e dicionários. Mas isso não se traduziu em qualquer prática de uso das línguas nacionais em Moçambique, nem da produção de textos ou outro material. Os órgãos de informação que publicavam páginas em línguas vernáculas foram objeto sistemático de pressão para o deixarem de fazer. De fato, penso que na década de 1950, deixaram de aparecer textos em línguas locais na imprensa escrita. Julgo que o Brado Africano, órgão da Associação Africana, na sua versão final já controlada pelo regime colonial, ainda manteve uma página em xironga na década seguinte. As línguas eram, porém, utilizadas pelo governo colonial nas emissões de rádio. A sua utilização como veículo oral era funcional ao sistema, por isso a usavam, mas a sua fixação como linguagem escrita era vista como potencialmente subversiva da dominação portuguesa. A principal experiência que há de 
produção de textos e de algumas literaturas de língua nacional vem dos protestantes, que ensinam as línguas nacionais nas escolas. Eles tinham versões da Bíblia em algumas línguas moçambicanas, como forma de fomentarem a leitura. Os protestantes eram fundamentalmente anglo-saxônicos e o conceito anglo-saxônico de colonização era de um governo indireto. Consideravam que cada comunidade tinha sua identidade cultural e a missão civilizadora, digamos assim, era estimular o desenvolvimento da sua capacidade endógena de, como grupo étnico, assimilar a modernidade ocidental. Era, sem dúvida, outra forma de colonizar e de assegurar a supremacia da civilização européia.

É preciso conhecer um pouco os ingleses para saber que, para além das coisas muito simpáticas que alguns dizem sobre o relativismo cultural, há uma outra coisa muito importante: os ingleses têm a certeza de que ninguém, que não seja britânico, pode ser um deles. Tanto é assim que o inglês é a única língua em que o "eu" é escrito com a letra maiúscula. O resto todo fica em volta do "eu"; o "tu" e o "ele" são minúsculas. Assim, nunca ninguém pode chegar a "eu", quer dizer, "eu" sou maiúsculo e "você" é minúsculo. Os outros grupos etno-lingüísticos podem (e devem) falar inglês, saber tudo, mas não serão nunca ingleses. Então, às questões das línguas, os protestantes davam um tratamento diferente do que davam os católicos nas missões presentes em Moçambique. O governo colonial via com grande apreensão a ação dos protestantes. Considerava-a "desnacionalizadora" e fez enorme pressão para que os protestantes ensinassem em português. Mas eles conseguiam fazer as duas coisas. Como tinham já codificadas as línguas, conseguiam produzir textos, principalmente religiosos. Quando, hoje, lemos um texto escrito numa língua africana, ficamos surpresos: por que certos sons aparecem com "K" e não com "Qu", ou "Ny" em vez de "nh", etc? Porque foi feito por ingleses para os anglosaxões e não por portugueses. Se você escreve com " $\mathrm{Gu}$ " ao invés de "K", o africano de Moçambique que lê na língua nacional reclama da grafia e considera-a "assimilada". Escrever "em africano" é usar o 
alfabeto britânico. Com a independência, a primeira medida tomada nas universidades foi criar um centro de línguas moçambicanas: selecionaram-se 4 das 16 línguas moçambicanas então consideradas e começou a se fazer um mapeamento dos estudos. Essas 4 línguas mais faladas cobriam, direta ou indiretamente, mais de $70 \%$ da população, ou seja, eram entendidas com relativa facilidade por essa percentagem dos moçambicanos, por similaridades com as línguas de outras comunidades (como, por exemplo, o espanhol e o português). Fazer esse estudo e as estruturações das línguas leva anos, principalmente quando há pouca gente para realizar tal trabalho. A língua portuguesa se tornou, pois, a língua franca, porque não privilegia nenhum dos grupos étnicos moçambicanos e é, de certa forma, um denominador comum aos indivíduos de todos eles. Se se optasse, por exemplo, pelo macua, língua falada por cerca de $40 \%$ da população moçambicana, quem não falasse macua ia ficar furioso e se perguntaria por que a sua própria língua materna foi desprezada. Eu fui Ministro da Informação a partir de 1980. Nessa época, a RM (Rádio Moçambique) emitia, em ondas curtas, em 13 línguas nacionais. Os locutores eram senhoras e senhores de uma certa idade e de baixa escolaridade oficial e começaram a sentir dificuldades com as novas tecnologias ou, simplesmente, passaram a se aposentar. Substituímo-los por novos locutores e começaram a chover cartas de protesto: os jovens jornalistas já não falavam bem as respectivas línguas, recheando-as de palavras em português e algumas em inglês. Ficamos num impasse e tivemos de estabelecer acordos de cooperação com as rádios dos países vizinhos (Zimbabué, Zâmbia, Malawi e Tanzânia) para mandarmos esses jovens estagiar com eles e melhorarem o domínio da língua, que naqueles países nunca deixara de ser estudada no tempo colonial.

O uso do português como língua de ensino também é um problema complicado: nas zonas rurais, ao mesmo tempo em que aprendia a codificar a língua na escrita, o camponês aprendia, efetivamente, o português e sua estrutura, que era bem diferente das línguas bantu. É como se nós, falantes do português, tivéssemos que aprender o $\mathrm{ABC}$ em 
alemão ou em chinês. Logicamente, o aproveitamento escolar era extremamente baixo, já que a pessoa tinha que aprender duas coisas difíceis ao mesmo tempo. Há 3 ou 4 anos, o governo iniciou um processo de alfabetização e aprendizagem do código escrito nas línguas maternas com a sua conversão paulatina para o português. Está treinando professores, pois poucos sabem bem escrever ou ler nas línguas nacionais. Em biologia, ciências, geografia, são raríssimos os professores capazes de ministrarem em ronga, ou nyanja, ou sena, etc. Há universitários no Núcleo das Línguas Moçambicanas que se formaram e foram ensinando outras pessoas, de modo que, aos poucos, vai se conseguindo um corpo de professores. Neste momento, o sistema de ensino de Moçambique funciona assim: o primeiro e o segundo anos são feitos na língua dos pais; só no terceiro ano escolar é que o português entra como segunda língua para, finalmente, ser a língua oficial no quarto. O mais importante é que o aluno aprende a codificar a escrita através de sua própria língua. Além disso, nas línguas bantu, o sistema aritmético é cumulativo: $1,2,3,4,5,5+1,5+2$. Não é decimal, é de base 5, como a numeração romana. Os problemas de ensino têm relação com toda a estrutura herdada e também com a produzida nos primeiros anos da independência, posto que vinculados ao tal cordão umbilical do colonialismo. Só agora isso está diminuindo, pouco a pouco. Esse processo tem que ser feito com maturidade e não com violência.

RC - A próxima questão é sobre a sua "tomada de consciência" com relação à luta contra o colonialismo. Na sua tese defendida recentemente, o senhor relata exemplos de situações discriminatórias vivenciadas pelos negros durante o período colonial, como o caso de Joaquim Chissano, impedido de ingressar no cinema em dada ocasião, e o de Rafael Arcanjo, empregado doméstico cuja prisão injusta foi protestada veementemente pelo senhor. Nossa pergunta é: a partir de que fato ou momento se deu a sua "tomada de consciência" a respeito das desigualdades raciais e sociais? 
José Luís - Esses itinerários são muito complicados de pôr numa cronologia. Tenho pensado nisso muitas vezes. Há um elemento que, para mim, é muito importante: eu era um menino, filho de administrador, vivia na administração e depois também na cidade, e assisti, desde muito pequeno, a cenas de grande violência. Quanto mais meu pai procurava manter-me longe, mais eu escapava para ver o que se passava. A violência a que eu assistia era institucional: castigos corporais, gente amarrada ou mesmo acorrentada; trabalhos forçados e humilhações de todo o tipo. Eram coisas comuns naquela sociedade, mas sempre me causaram um grande mal-estar. A repulsa que então sentia, não era pela discriminação racial - porque esta estava absolutamente naturalizada, era algo natural —, mas por essa violência explícita. Vi gente ser batida, ficar com as mãos inchadas por ser batida; vi homens chorando como crianças pelas torturas sofridas em público; eram coisas horriveis. Já na cidade, no princípio dos anos 60 — eu tinha 11, 12 anos —, vi gente passar para o trabalho forçado, em longas filas de seis, sete homens, com correntes nos pés. Iam ligados uns aos outros e carregando a corrente na mão para poderem caminhar, os instrumentos de trabalho no ombro. Passavam de manhã para ir ao serviço e à tarde voltavam para cadeia. Isso foi uma coisa sempre presente, sempre vi isso com grande indignação. Nesses anos da década de 1950 comecei um processo de reflexão sobre essas coisas. Naturalmente, em conjunto com colegas de escola, alguns dos quais militariam depois nas fileiras nacionalistas. Era um período no qual, não obstante a crescente crítica ao sistema, eu ainda convivia tranqüilamente com o racismo cotidiano que me surgia como naturalizado: a sociedade era simplesmente assim, pensava eu! Incomodavam-me, digamos, as manifestações acentuadas de racismo. Quando eu entrava no ônibus e via um senhor negro, velho, ser maltratado e mandado para o último banco, sentia-me mal. Mas se ele entrava e se sentava no último banco, isso não me perturbava. Recordo que o desrespeito com os velhos sempre me chocou. Naquela altura, 
qualquer criança branca podia bater em um velho negro sem que isso fosse, necessariamente, motivo de punição ou sequer repreensão. A sociedade colonial não achava isso uma falta grave. Com 16 anos, eu já estava no ensino pré-universitário, fase em que se comecei a ter pretensões e algumas preocupações de natureza intelectual e a querer pôr em causa e discutir alguns assuntos. Em 1958, há as eleições do Humberto Delgado contra o Américo Tomás e o espírito contestatário levou o nosso grupo de amigos a decidir assistir aos comícios da campanha eleitoral, principalmente os da oposição. Concordávamos com os ideais de liberdade, democracia e ficamos envolvidos. Para mim, foi um momento de questionamento dessa naturalização com que me habituara a ver a sociedade. Assistimos à fraude eleitoral. Íamos às sessões da oposição, mas também às do governo, exatamente para não ficarmos diferenciados. Mesmo assim, o reitor do liceu nos chamou éramos um grupo de 7 ou 8 - e disse que aquilo era coisa para adultos, não para estudantes, e isso também nos irritou. A nossa discussão centrava-se no fascismo, na falta de liberdade e democracia; ainda não discutíamos propriamente o colonialismo. Depois, terminei o liceu e fui para a universidade em Coimbra, onde retomei o contato com colegas e amigos moçambicanos e conheci angolanos, caboverdianos, etc. O anticolonialismo dominava as preocupações de muitos dos estudantes das colônias e, para mim, foi um novo campo de aprendizagem e de discussão. Em 1960, dá-se a independência do Congo e segue-se a tentativa de secessão de Catanga, liderada por Moïses Tshombe - um vendido - com o apoio dos belgas. Catanga era a província congolesa mais rica em minérios. Nós, estudantes das colônias em Coimbra, discutimos muito a questão congolesa. Aos poucos, o grupo foi se polarizando entre os que achavam que Lumumba era a solução para o Congo e os que tomavam partido de Tshombe. Isso é muito interessante porque os tshombistas ficaram todos colonialistas e em Portugal, enquanto os lumumbistas - eu tornei-me um deles - acabaram, em grande número, posicionando-se pelos ideais nacionalistas. A discussão sobre o Congo foi, realmente, um divisor de águas. Nessa época, 
também acabava de acontecer a Revolução Cubana com todo o romantismo que a acompanhou e simbolizando os ideais de justiça e eqüidade social, consubstanciados no socialismo. Cuba e Fidel tiveram então grande impacto entre nós. Em 1961, regressei a Moçambique para prestar o serviço militar obrigatório para Portugal: fui incorporado pelas tropas locais (guarnição de Moçambique) e isso me permitiu prestar serviço em Moçambique, e evitar ser mobilizado para Angola, que, naquela altura, era onde acontecia a guerra. De maio de 61 a agosto de 62, estivera trabalhando em Lourenço Marques à espera da incorporação militar. Nesse momento, já estava politizado e convencido da necessidade da luta de libertação nacional. Seguia com entusiasmo e emoção a luta em Angola. Integrei, nesses meses, um grupo de jovens igualmente imbuídos de idéias nacionalistas. Na sua maioria era constituído por brancos, mas foi aí que conheci o Luís Bernardo Honwana, que ainda não tinha escrito o livro. Organizávamos uma página literária quinzenal,"O Despertar”, no jornal "Notícias”, o principal cotidiano de Maputo. Passamos a trocar livros e a nos encontrarmos regularmente para discutir os assuntos mais diversos. Tínhamos, naquela altura, uma grande paixão pela leitura. Lia-se muita literatura brasileira, francesa, do pós-guerra, alguma literatura americana, raros autores portugueses. Líamos avidamente Jorge Amado e Graciliano, Lins do Rego e Raquel de Queiroz, Manuel Bandeira e Drummond. Lembro-me dos livros de Vailland e Simone de Beauvoir, do teatro de Sartre e Ionesco, de Aragon e Élouard. Dos americanos, Richard Wright, Hemingway, Dos Passos, Faulkner e Steinbeck estavam entre os mais procurados. Conhecíamos, de Portugal, alguns neorealistas e o nosso preferido era Soeiro Pereira Gomes. Falo de alguns dos autores que me ocorrem para dar uma idéia das preocupações do grupo. Paralelamente, líamos o que nos caía em mãos sobre o nacionalismo africano e o socialismo. Foi um período de grande estudo para mim, de muita leitura e também de grande amadurecimento sobre o mundo em que vivia. Aí, já estou com 20 anos, vivendo a realidade moçambicana e com um pensamento crítico em estruturação. A minha 
percepção do colonialismo passa a ser outra, bem mais severa e radical. O racismo, com toda sua carga de injustiças e desigualdades, torna-se, para mim, uma obsessão. Revolto-me comigo próprio por não ter sabido lê-lo no cotidiano colonial bem mais cedo. Em Coimbra, as percepções eram de natureza teórica, mas, em Moçambique, comecei a me aperceber na prática das manifestações da monstruosidade colonialista. A presença no serviço militar não perturbou as minhas idéias. Pelo contrário: fui oficial instrutor de tropas moçambicanas, africanas, negras, e essa foi outra grande experiência. Conheci dezenas de camponeses que vinham do interior para treinar e com os quais eu tinha uma interação desde às seis da manhã até às cinco da tarde, de modo que comecei a conhecer suas histórias de vida, alguns de seus problemas e dificuldades. Foi um momento de muita aprendizagem. E é nesse período que conheço o Rafael Arcanjo, que trabalhava na casa de meus pais. A distância entre o quartel e a casa dos meus pais era de uns 30 quilômetros; eu ia para lá nos fins de semana e, muitas vezes, nos fins da tarde, durante a semana. Não era o caso de escrever isso na tese, no momento em que conto a história de Rafael, mas quando fui falar com a polícia para soltá-lo, fui fardado, porque estava para ir ao quartel. Fui fardado para impressionar o policial, pois eu era oficial e isso tinha seu efeito. Rafael ficou assustado, desestruturado, porque, para ele, a forma de ler o colonialismo sofreu um importante abalo com aquele episódio! Esse período no exército foi um período muito formativo para mim, e também um período de grandes angústias. Foram anos de problemas existenciais muito profundos, não só sobre o que eu queria da vida, mas porque eu estava envolvido em uma estrutura que estava do lado contrário ao que eu desejava e acreditava. Porém, tinha que ensinar os soldados a serem soldados, seria um assassino se não os ensinasse a se defenderem. Mas ensinando-os, também sabia que eles poderiam, um dia, matar combatentes da liberdade com os quais me sentia profundamente solidário. Foi uma situação muito complicada! Nesse período também trabalhei no jornal como colaborador. Depois, saí do serviço militar e arranjei um emprego. 
No dia em que saí do serviço militar, eu, juntamente com meu pai, jogamos um pequeno bilhete de loteria e saiu a cada um dez mil dólares que, naquela época, era uma fortuna! Meu pai, com seus dez mil dólares, comprou um apartamento. Quanto a mim, fiz as contas e cheguei à conclusão que, com dois mil e quinhentos dólares por ano, viveria na Europa. Então, abandonei o emprego e fui para a Europa. Minha principal preocupação era procurar contato com a FRELIMO, porque em Moçambique eu não conseguia, não havia canais para isso, a barreira racial era tão forte que qualquer aproximação era desconfiada. Primeiro, fui para a Alemanha, depois para a Itália, de onde escrevi para um amigo do meu grupo do liceu que estava na FRELIMO. Eu não sabia o endereço dele, somente que freqüentava a Universidade de Lomonosov e foi isso que escrevi no envelope. A carta, felizmente, chegou ao destino para prestígio dos serviços postais soviéticos. No ano seguinte, em 1967, tive um encontro com o Marcelino dos Santos, em Roma, e se estruturou a minha relação com a FRELIMO. Passei a trabalhar segundo as orientações que a FRELIMO me dava, e ali eu já estava politicamente orientado. A Itália era muito rica do ponto de vista político, e vivi ali o período da contestação estudantil de 1967/69. Foi de grande riqueza crítica e intelectual e essa experiência reforçou bastante minha formação política e teórica. A minha formação nacionalista e de militante acabaria, porém, por ser estruturada na atividade clandestina, na FRELIMO. Alonguei-me um pouco porque queria dizer que a formação política nacionalista foi um processo lento, que se foi construindo de passo em passo, a partir daquele meu repúdio pela violência colonial, o que nunca me permitiu a adesão total ao fato colonial. Mesmo tendo aderido a algumas coisas - na minha juventude, logicamente —, sempre havia um “mas”. E, em cima do "mas", acabou por se construir um repúdio da sociedade colonial. E depois houve um processo de traição objetiva pelo qual passei. Traí meu grupo social para ser coerente e fiel à minha consciência. É muito complicado, porque, num processo como este, enfrenta-se um conflito entre a razão e os afetos. É nesse momento que começa a nascer uma 
consciência. São situações indiscutivelmente dolorosas, que exigem determinação, convicção dos próprios sentimentos e alguma coragem nas escolhas decisivas. Mas há um momento em que você se diz: "Se não faço a opção agora, durante toda a minha vida não vou conseguir viver comigo mesmo”. Isso é decisivo.

RC - O senhor se lembra desta foto?

[Endereço para acesso na internet: < groups.msn.com/k2ohbqmalOoreimb3r1 uq1jlo6/basquetebol. msnw?action=ShowPhoto\&PhotoID=7258 >

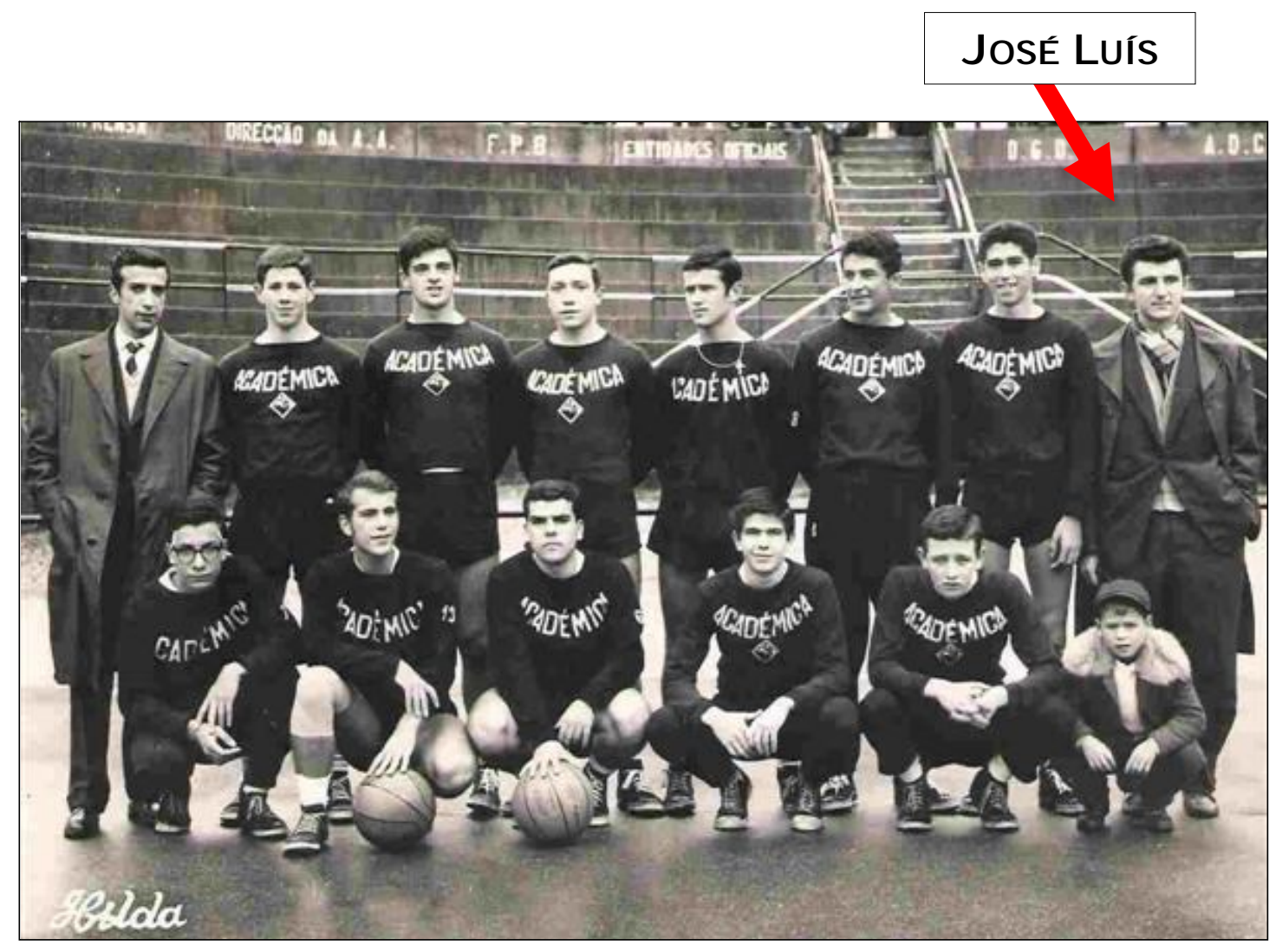

José Luís - Lembro! Isso foi no tempo de Coimbra. Ainda com 19 anos fui treinador de basquete dos juniores do clube da Universidade de Coimbra, a Acadêmica. E fui, nessa qualidade, campeão nacional português! Essa equipe treinada por mim ganhou o campeonato nacional em Portugal. Eu jogava basquete e futebol em Moçambique e ingressei na Acadêmica de Coimbra quando fui para Portugal. Cheguei a jogar um campeonato na equipe principal, como suplente. E depois, 
os jovens juniores da Acadêmica tiveram uma crise, precisavam de um treinador e, então, pediram-me que pegasse neles no fim de uma época. Como tínhamos uma boa relação, eles pediram à direção que eu os treinasse no ano seguinte e, justo nesse ano, ganhamos o campeonato nacional em Portugal. Fomos campeões! Eu tenho medalha e tudo. Três anos mais tarde, em Moçambique, voltei a treinar uma equipe de juniores, a do Desportivo, e voltei a ser campeão. Falo pouco da vida de treinador, mas ela deu-me, realmente, muita satisfação.

RC - Julgamos que todos os que aparecem na foto eram colegas de faculdade ou de turma naquela época. Estamos certos?

José Luís - Só dois andavam na universidade. Os restantes eram estudantes do ensino secundário e pré-universitário. Eles eram dois a três anos mais jovens que eu, mas isso, naquela idade, fazia a diferença entre os primeiros anos da universidade e os últimos anos dos liceus.

RC - E todos eram amigos?

José Luís - Sim, sim, éramos muito amigos, sem dúvida. Formávamos uma equipe coesa.

RC - Levando em conta o fato de alguns, como Pinto Coelho e Amoroso Lopes, terem tomado partido de Portugal, qual foi a repercussão da guerra de libertação no relacionamento dos então amigos?

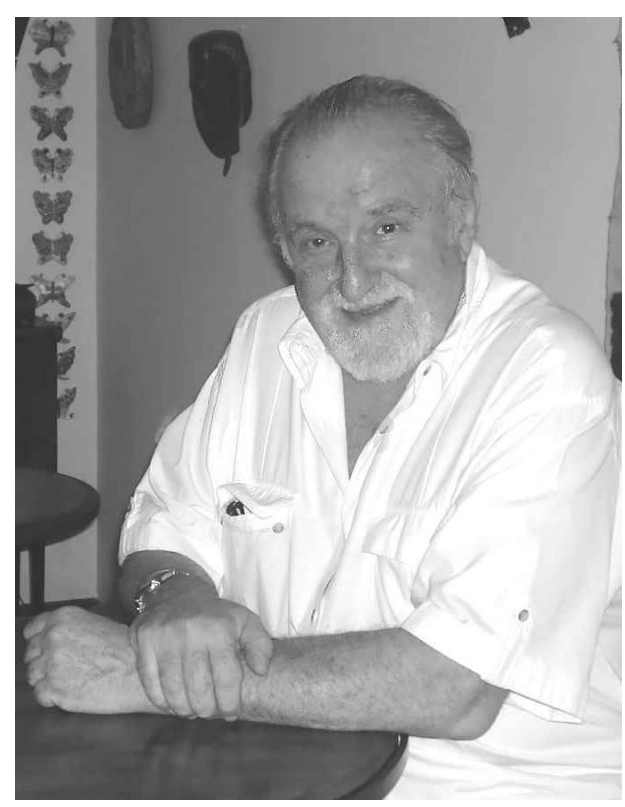

José Luís - Olha, o problema é o seguinte: na vida, há decisões que se tomam por opção e outras que se tomam por omissão. Esses jovens não tomaram, propriamente, partido, mas acabaram envolvidos, como 
tantos milhares de outros, por omissão. Quero dizer: eles eram portugueses, foram convocados para fazer o serviço militar, o serviço militar mandou-os para a guerra, eles foram para a guerra e, como qualquer soldado, lutaram e voltaram todos para casa, felizmente vivos e inteiros. Esse foi, fundamentalmente, o itinerário deles. Eu compreendo o processo e não me cabe o direito de atribuir culpas a nenhum deles, só porque, com experiência de vida diferente, desenvolvi uma diferente consciência política e ética que me levou à opção de militar nas fileiras nacionalistas e contribuir para a luta de libertação nacional. Inclusive, para muitos colonos e alguns portugueses de Portugal que me conheciam, a minha escolha terá sido difícil de compreender. Para eles, terei, eventualmente, feito um trabalho que eles não aprovam, principalmente porque usei a minha condição socialmente privilegiada de branco, com acesso e facilidades na sociedade colonial, para colher informações que serviam à luta de libertação contra as mordomias de que se beneficiavam. Mas realizei esse trabalho com grande dedicação e consciente dos meus deveres como moçambicano e estou muito orgulhoso de tê-lo feito. Muitos colonos ficaram, portanto, furiosos quando perceberam que usei o seu complexo de superioridade racista para combatê-los. Não foi o caso destes dois amigos a que se acabam de referir. Eles estavam desligados dos interesses diretos coloniais. A gente se encontrou depois da independência de Moçambique no mesmo clima de amizade e confraternização que tínhamos cultivado dentro da equipe de basquete. Enquanto foi guerra, a História nos colocou em campos opostos, como nacionais de dois países em conflito, mas quando a guerra acabou, soubemos de ambos os lados recuperar a nossa humanidade e retomar os laços afetivos que, como seres humanos, tínhamos construído. Da minha parte, compreendi a omissão deles, condicionados a não tomarem posição contra a guerra: não concordei, mas compreendi. Da parte deles, também não houve problema. Eles respeitaram a opção, embora, certamente, discordassem dela. Os amigos que vieram a Moçambique me procuraram, abraçamo-nos, visitaram-me em casa, 
conversamos muito, bebemos aos velhos tempos, etc. Já o mesmo não acontece com outros colegas, pessoas da minha geração em Moçambique, e com quem eu tinha inclusive relações de amizade, que fizeram opções políticas para combater a administração de Moçambique. Aí já é uma outra situação. Com essa gente, as relações são frias ou mesmo inexistentes. Os campos permanecem divididos, porque eles não abandonaram suas convicções racistas e coloniais.

RC - Porque, nesse caso, foi uma escolha...

José Luís - Exatamente. Nesse caso, não mantenho relações. Eu também não espero que eles respeitem as minhas opções políticas, porque são as minhas opções políticas contra as razões deles. Portanto, está tudo certo. Mas aí não tem relação.

RC - Com relação ao time de basquete, o que havia era o embate entre a opção política e a obrigação de cumprir o serviço militar?

José Luís - Sim, a opção e a obrigação, exatamente. Os que foram levados pelas circunstâncias são logicamente diferentes dos que provocaram as circunstâncias. Agora, inclusive devido à tese, eu procurei dois destes, colegas dos tempos da adolescência em Moçambique, e pedi para entrevistá-los com vista à minha pesquisa. Um deles, com o qual eu nunca tinha tido uma confrontação antes de os nossos caminhos se dividirem, foi solícito. Com o outro, ao contrário, foi impossivel fazer a entrevista, porque ele é um indivíduo de tal forma megalômano que a possibilidade de contar a sua história para alguém o entusiasmou demais. A entrevista foi alucinante, ele pegou o microfone e falou durante quatro horas. Não deu para fazer nenhuma pergunta! Ainda não compreendi se me queria convencer ou se me queria provocar ou, ainda, se simplesmente queria verbalizar uma história que ele, no seu intimo, sabe ser falsa, mas que precisa verbalizar para the dar consistência. 
$\mathbf{R C}$ - Ele falou o que bem entendeu...

José Luís - Falou o que bem entendeu, disse as coisas mais incongruentes do mundo. Peguei o gravador e pensei: "Vou-me embora antes que ele fique com o meu gravador!" Foi um desastre, tem entrevista que é um desastre! Essa foi completamente alucinante. Com o outro, eu consegui fazer a entrevista; mas com esse, foi impossível. 